\title{
Role of excretory graft function for erythropoietin formation after renal transplantation
}

\author{
K.-U. ECKARDT, U. FREI*, V. KLIEM*, C. BAUER, K. M. KOCH* \& A. KURTZ, Physiologisches \\ Institut der Universität Zürich, Zürich, Switzerland, and*Abteilung Nephrologie, Zentrum Innere Medizin \\ und Dermatologie, Medizinische Hochschule, Hannover, FRG
}

Received 8 September 1989 and in revised form 19 February 1990

\begin{abstract}
To examine the role of renal excretory function for erythropoietin (EPO) formation we have determined the kinetics of plasma immunoreactive EPO (irEPO) in patients with end-stage renal disease undergoing renal allotransplantation (RTX).

In 13 patients with immediate excretory graft function (imGF) and stable haemoglobin $(\mathrm{Hb})$ concentrations (median $\mathrm{Hb} 9.5 \mathrm{~g} \mathrm{dl}^{-1}$ and median irEPO $18 \mathrm{mU}$ $\mathrm{ml}^{-1}$ before RTX) irEPO increased significantly on day 4 after RTX to a median value of $29 \mathrm{mU} \mathrm{ml}^{-1}$ and 2 days later reached a plateau of $34.4 \pm 3.3 \mathrm{mU} \mathrm{ml}^{-1}$ (mean \pm SD of daily median values during days $6-20$ ). In patients with imGF having acute blood loss and subsequently receiving transfusions, irEPO responded in an inverse fashion to changes in $\mathrm{Hb}$ concentrations.

In 12 patients with delayed graft function (dGF) (median $\mathrm{Hb} 8.8 \mathrm{~g} \mathrm{dl}^{-1}$ and median irEPO $15 \mathrm{mU} \mathrm{ml}^{-1}$ before RTX) irEPO levels during the period of excretory failure remained either unchanged or displayed marked variations with peak values greatly exceeding those of patients with imGF. These variations were not related to changes in $\mathrm{Hb}$ concentrations and irEPO levels did not change following alterations in $\mathrm{Hb}$ concentrations. Upon recovery of excretory function irEPO approached the values found in patients with imGF.

The results suggest that an intact excretory renal function is not a prerequisite for the capability to produce EPO, but correlates with the oxygen-dependent regulation of EPO formation.
\end{abstract}

Keywords. Delayed graft function, immediate graft function, radioimmunoassay, renal anaemia.

Preliminary results were presented in abstract form at the 19 th Annual Meeting of the German Society of Nephrology, Göttingen 1988.

Abbreviations: ADPKD, autosomal dominant polycystic kidney disease; dGF, delayed graft function; EPO, erythropoietin; imGF, immediate graft function; irEPO, immunoreactive erythropoictin; RTX, renal transplantation; VUR, vesicoureteric reflux.

Correspondence: Dr K.-U. Eckardt, Physiologisches Institut der Universität Zürich, Winterthurerstrasse 190, CH 8057 Zürich, Switzerland.

\section{Introduction}

Patients suffering from end-stage renal disease (ESRD) generally develop an anaemia that results predominantly from inappropriately low erythropoietin $(E P O)$ production by the damaged kidneys $[1,2]$ The physiological mechanisms underlying EPO formation and their possible alterations during kidney disease are not yet determined. In particular, it is not known whether the inappropriate EPO formation during ESRD results from destruction of the EPOproducing cells or functional alterations accompanying excretory renal failure. Recent observations in acute renal failure suggest that EPO formation may be impaired when there is functional failure but no chronic structural damage to the kidney $[3,4]$. To further elucidate the role of excretory renal function for the biosynthesis of EPO, we decided to study the relationship between EPO formation and renal excretory function in renal allograft recipients, in whom functioning grafts displayed a temporary delay in the onset of excretory function.

Previous studies addressing the correction of anaemia after renal transplantation (RTX), have shown that increases in EPO levels precede the reticulocytosis and rise in haematocrit following RTX $[5,6,7]$ and in some cases EPO rose as early as the first to third posttransplant day [5,7]. An investigation by Besarab et al. [6] includes some data on EPO formation in a subgroup of patients with delayed graft function. While EPO did generally not increase until excretory graft function commenced, increments in some patients appeared to be related to differences in immunosuppressive regimens. However, in these patients, EPO values were not related to haemoglobin concentrations and sampling intervals were at least 3 days. Furthermore, a very recent study reports on a biphasic increase in EPO, with a first increase that was independent of graft function [8].

In the present investigation we determined plasma immunoreactive EPO (irEPO), haemoglobin and serum creatinine concentrations daily for at least 3 weeks following RTX in patients under standardized immunosuppressive therapy, and compared the time 
course and magnitude of increases in irEPO in patients with immediate graft (imGF) function with that in patients with delayed graft function (dGF).

\section{Patients and methods}

\section{Patients}

A total of 27 consenting patients who underwent renal transplantation during two study periods were included in this investigation. Patient characteristics and the underlying renal disease are given in Table 1. None of the patients had received transfusions at least 3 months before RTX or had been treated with recombinant EPO. According to excretory graft function, patients were divided into two groups with immediate and delayed graft function, respectively. ImGF was considered present if (1) serum creatinine values declined continuously and approximately exponentially after RTX, and (2) reached values less than $300 \mu \mathrm{mol} \mathrm{l}^{-1}$ within, maximally, 7 days $(n=15)$.

Table 1. Clinical details of grafted patients studicd

\begin{tabular}{|c|c|c|c|c|}
\hline Patient & $\begin{array}{l}\text { Cause of renal } \\
\text { failure }\end{array}$ & Sex & $\begin{array}{l}\text { Age } \\
\text { (years) }\end{array}$ & $\begin{array}{l}\text { Months } \\
\text { on HD }\end{array}$ \\
\hline \multicolumn{5}{|c|}{ (a) Immediate graft function } \\
\hline I & glomerulonephritis & $\mathrm{m}$ & 56 & I1 \\
\hline 2 & glomerulonephritis & $\mathrm{m}$ & 48 & 81 \\
\hline 3 & pyelonephritis & $\mathrm{m}$ & 20 & 8 \\
\hline 4 & ADPKD & f & 51 & 21 \\
\hline 5 & interstitial nephr. & f & 56 & 41 \\
\hline 6 & $\begin{array}{l}\text { pyelonephritis and } \\
\text { unilat. renal } \\
\text { hypoplasia }\end{array}$ & $\mathrm{m}$ & 23 & 16 \\
\hline 7 & pyelonephritis, VUR & $\mathrm{m}$ & 48 & 171 \\
\hline 8 & glomerulonephritis & $\mathrm{m}$ & 54 & 49 \\
\hline 9 & $\begin{array}{l}\text { nephrosclerosis and } \\
\text { urate nephropathy }\end{array}$ & $\mathrm{m}$ & 63 & 23 \\
\hline 10 & IgA nephropathy & $\mathrm{m}$ & 31 & 11 \\
\hline 11 & pyelonephritis & $\mathrm{m}$ & 17 & 18 \\
\hline 12 & urate nephropathy & $\mathrm{m}$ & 62 & 79 \\
\hline 13 & glomerulonephritis & $\mathrm{m}$ & 67 & 34 \\
\hline 14 & nephrosclerosis & $\mathrm{m}$ & 62 & 12 \\
\hline 15 & glomerulonephritis & $\mathrm{m}$ & 48 & 54 \\
\hline \multicolumn{5}{|c|}{ (b) Delayed grafi function } \\
\hline 16 & unknown & f & 26 & 12 \\
\hline 17 & glomerulonephritis & $\mathrm{m}$ & 51 & 106 \\
\hline 18 & focal sclerosis & $\mathrm{m}$ & 49 & 95 \\
\hline 19 & glomerulonephritis & $\mathrm{m}$ & 27 & 64 \\
\hline 20 & renal dysplasia & $\mathrm{m}$ & 23 & 34 \\
\hline 21 & diabetic nephropathy & $\mathrm{m}$ & 48 & 11 \\
\hline 22 & diabetic nephropathy & $\mathrm{m}$ & 51 & 34 \\
\hline 23 & glomerulonephritis & i & 30 & 100 \\
\hline 24 & focal sclerosis & $\mathrm{m}$ & 42 & 103 \\
\hline 25 & pyelonephritis, VUR & $\mathrm{m}$ & 32 & 108 \\
\hline 26 & glomerulonephritis & $\mathrm{m}$ & 41 & 39 \\
\hline \multirow[t]{2}{*}{27} & nephrocalcinosis & & & \\
\hline & (urogen. tuberculosis) & f & 44 & 84 \\
\hline
\end{tabular}

HD, hemodialysis; ADPKD, autosomal dominant polycystic kidncy disease; VUR vesicoureteric reflux.

All patients received the first transplant except patients no. 16,18 20 (second transplant) and 23 (fourth transplant). Patients no 3 and 11 received live-related grafts.
Patients were grouped as having dGF when serum creatinine values (1) either did not decline spontaneously after RTX so that temporary continuation of haemodialysis was required $(n 8)$ or the decline in creatinine levels was protracted $(n=4)$, and (2) serum creatinine values less than $300 \mu \mathrm{mol} \mathrm{I}^{-1}$ were reached within 30 days post-RTX. Patients who did not meet the criteria of one of the two groups either because graft failure was prolonged or irreversible $(n=5)$ or worsening of graft function occurred after serum creatinine levels of $300 \mu \mathrm{mol} 1^{-1}$ had been reached $(n=7)$, were not included.

In all patients included, warm ischaemia time of grafts was less than $7 \mathrm{~min}$; cold ischaemia time was $1420(1252-1533) \mathrm{min}$ and $1718(1476-2145) \mathrm{min}$ (median and interquartile range) in patients with imGF and dGF, respectively.

\section{Immunosuppressive therapy}

Standardized immunosuppressive therapy consisted of cyclosporine A $\left(10 \mathrm{mg} \mathrm{kg}^{-1} \mathrm{day}^{-1}\right.$ started immediately post-transplantation and dose later adjusted to achieve serum levels of $200-300 \mathrm{ng} \mathrm{ml}^{-1}$ ) and steroids ( $500 \mathrm{mg}$, $250 \mathrm{mg}$ and $100 \mathrm{mg}$ methylprednisolone on days 0,1 and 2 , and $1 \mathrm{mg}$ prednisolone $\mathrm{kg}^{-1} \mathrm{day}^{-1}$ started on post-transplant day 3 and reduced daily by $0.1 \mathrm{mg} \mathrm{kg}^{-1}$ day $^{-1}$ during the initial 7 days, and then by $2.5 \mathrm{mg}$ every 14 days to a maintenance dose of $7.5 \mathrm{mg} \mathrm{day}^{-1}$ ). Additionally, azathioprine $\left(2 \mathrm{mg} \mathrm{kg}^{-1}\right)$ was given to patients with acute graft rejection or those on high immunological risk, i.e. with preformed cytotoxic antibodies or rejection of previous grafts.

\section{Additional drug treatment}

All patients were on antacids and local antimycotic agents. Other drugs were calcium antagonists, betablocking agents or converting enzyme inhibitors for treatment of hypertension and loop diuretics if required.

Peripheral venous blood was withdrawn from all patients before RTX and daily between 08.00 and 10.00 for at least 3 weeks and up to 56 days following RTX, for determinations of plasma irEPO concentrations, serum creatinine and haemoglobin concentrations.

\section{Measurement of erythropoietin}

EPO was measured in heparinized plasma samples by radioimmunoassay as described previously [9]. In brief, $100-\mu \mathrm{l}$ samples plus $20 \mu \mathrm{l}$ of $30 \%$ bovine serum albumin were incubated for $24 \mathrm{~h}$ with $100 \mu \mathrm{l}$ rabbit antiserum raised against pure recombinant human EPO. One-hundred $\mu \mathrm{l}$ of $\left({ }^{125} \mathrm{I}\right)$ iodotyrosyl-EPO $\left(8 \times 10^{-11} \mathrm{~mol} \mathrm{l}^{-1}\right.$; Amersham International, Amersham, UK) were then added and after an additional incubation period of $24 \mathrm{~h}$ separation of free and bound 
ligand was carried out using a second antibody technique. The second International Reference Preparation of human urinary EPO (WHO) was used as standard. The lower detection limit of the assay is $5 \mathrm{mu}$ $\mathrm{ml}^{-1}$, the interassay coefficient of variation is $6.7 \%$ for a sample containing $44.2 \pm 3.0 \mathrm{mu}$ irEPO $\mathrm{ml}^{-1}$ (mean $\pm \mathrm{SD}$ ). Geometric mean EPO level for nonanaemic adults is $17.9 \mathrm{mu} \mathrm{ml}^{-1}(95 \%$ range from $11-31$ mu $\left.\mathrm{ml}^{-1} ; n=84\right)$.

\section{Serum creatinine levels and haemaglobin concentrations}

These were determined by routine laboratory methods.

\section{Statistics}

Unless otherwise indicated, data are presented as median and interquartile range (in brackets). Mann-
Whitney test and Wilcoxon signed-rank test were used to compare median values of unpaired and paired observations, respectively. Student's unpaired $t$-test was used to compare mean values. A $P$ value $<0.05$ was considered significant.

\section{Results}

\section{Patients with imGF}

EPO formation was analysed separately in two patients experiencing marked changes in haemoglobin concentrations in the post-transplant phase and in the remaining patients with stable haemoglobin $(n=13)$. Figure 1 shows the time-course of plasma irEPO levels following RTX in these latter 13 patients with imGF in relation to serum creatinine and haemoglobin concentrations. Parallel to the decline in serum creatinine

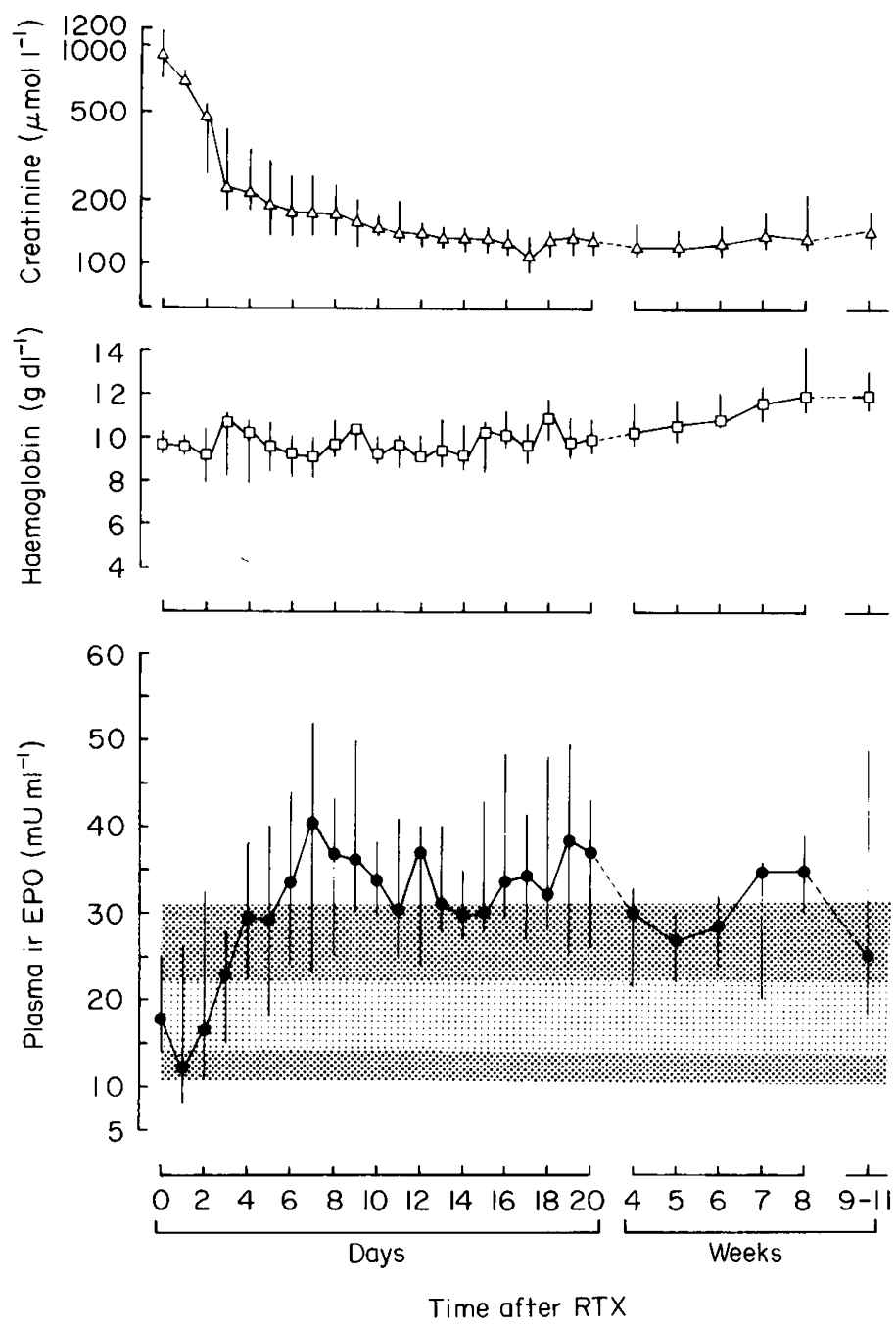

Figure 1. Temporal pattern of serum creatinine (upper), haemoglobin (middle) and plasma irEPO (lower) concentrations in patients with imGF after RTX. Data are median values and interquartile range in 13 patients studied from days 0 to 20 and in seven of these patients additionaly studied between weeks 4 and 11 . For comparison, interquartile range and $95 \%$ range of serum irEPO in healthy adults is included (stippled). Following RTX EPO levels were first significantly elevated on post-transplant day 4 $(P<0.02)$. 
values, median irEPO level increased significantly from $18(14-25) \mathrm{mU} \mathrm{ml}^{-1}$ to 29 (22-38) $\mathrm{mU} \mathrm{ml}^{-1}$ on post-transplant day $4(P<0.02)$ and on day 6 reached a plateau of $34.4 \pm 3.3 \mathrm{mU} \mathrm{ml}$ (mean $\pm \mathrm{SD}$ of daily median values on days 6-20). During the first three post-transplant weeks none of these patients exhibited any variation in haemoglobin concentrations greater than $2 \cdot 2 \mathrm{~g} \mathrm{dl}^{-1}$ or received transfusions. In seven of these patients irEPO and haemoglobin concentrations were further determined weekly up to week 8 following RTX, and between weeks 9 and 11. irEPO values were $31.3 \pm 3.7 \mathrm{mU} \mathrm{ml}^{-1}$ (mean $\pm \mathrm{SD}$ of weekly median values) between weeks 4 and 8 , and median irEPO level was $25(18-49) \mathrm{mU} \mathrm{ml}^{-1}$ between weeks 9 and 11 .
Haemoglobin concentrations increased continuously from $10 \cdot 3(9 \cdot 3-11.2) \mathrm{g} \mathrm{dl}^{-1}$ in week 4 to $12.1(11.6-$ 12.7) $\mathrm{g} \mathrm{dl}^{-1}$ between weeks 9 and 11 (Fig. 1).

Two additional patients with imGF (no.. 14. 15; Table 1) experienced a temporal marked decline in haemoglobin concentrations between post-transplant days 29 and 35, and 14 and 33, respectively. Both patients showed significant increases in their irEPO levels during these periods. In one patient (no. 14) in whom the haemoglobin concentration fell from 9 to $5.6 \mathrm{~g} \mathrm{dl}^{-1}$ due to wound bleeding, and subsequently rose to $10 \cdot 2 \mathrm{~g} \mathrm{dl}^{-1}$ following surgical revision and transfusion, irEPO values increased from a median value of $31 \cdot 5(28-38) \mathrm{mU} \mathrm{ml}^{-1}$ before blood loss (days
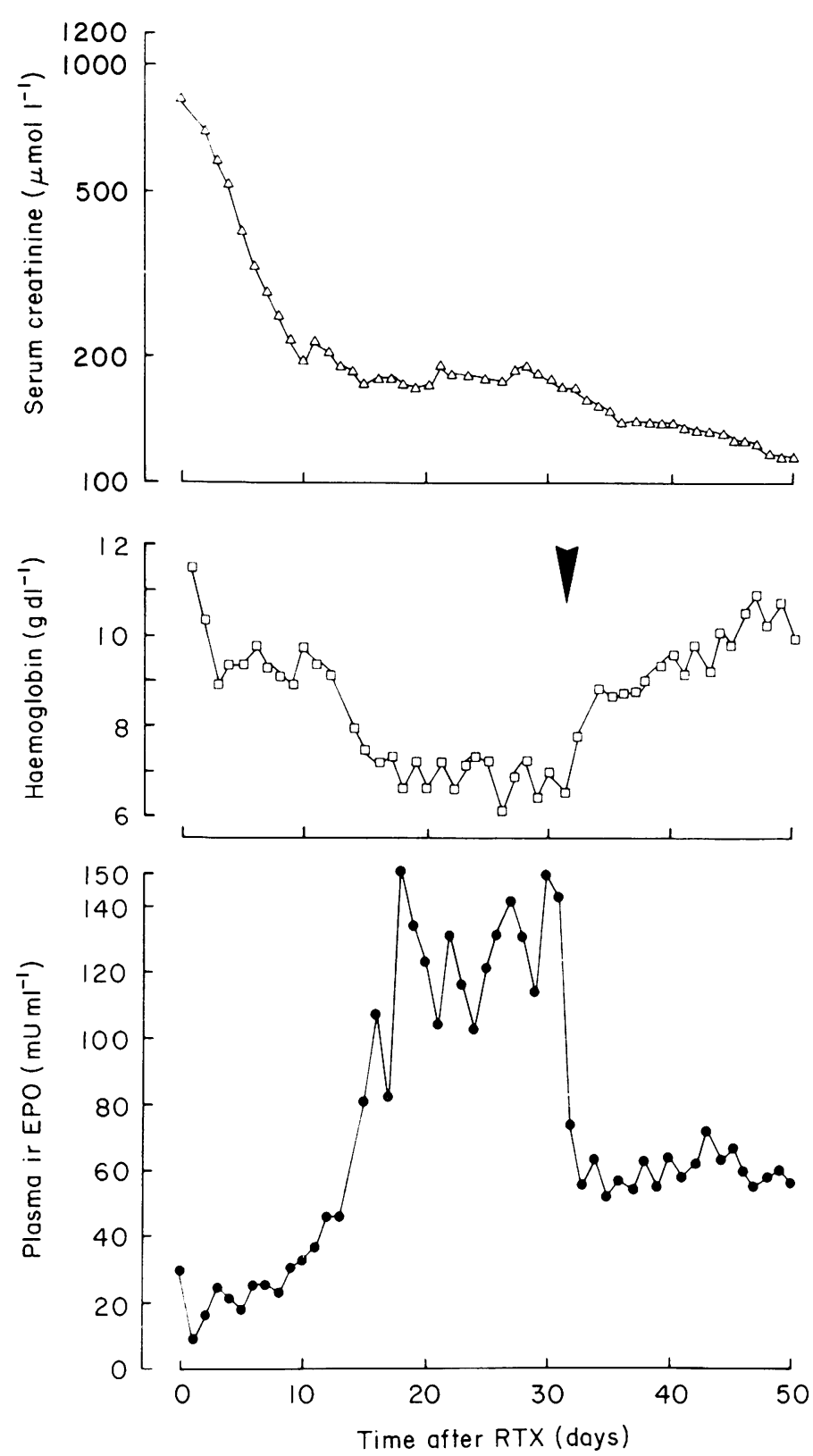

Figure 2. Time-course of serum creatinine (upper), haemoglobin (middle) and plasma irEPO (lower) concentrations in a patient experiencing acute blood loss due to gastrointestinal bleeding and subsequently receiving transfusion of two units of erythrocytes on day 31 following RTX (arrow). 
4-29) to a median value of $88(71-114) \mathrm{mU} \mathrm{ml}^{-1}$ during the reduction in haemoglobin concentrations, and after transfusion declined again to a median value of $15.5(11-17) \mathrm{mU} \mathrm{ml}^{-1}$. The time-course of EPO levels in relation to haemoglobin for the other patient (no. 15) is depicted in Fig. 2. Parallel to the reduction in haemoglobin concentrations due to gastrointestinal bleeding, irEPO increased to a median value of 130 $(107-133) \mathrm{mU} \mathrm{ml}^{-1}$.

\section{Patients with $d G F$}

In patients with delayed graft function, EPO formation following RTX was much more variable. The temporal pattern of plasma irEPO levels and haemoglobin concentrations in the whole group of 12 patients with $\mathrm{dGF}$, during the time-period when serum creatinine concentrations were higher than $300 \mu \mathrm{mol} \mathrm{I}^{-1}$, is illustrated in Fig. 3. For comparison, interquartile range (dark stippled) and absolute range (light stippled) of values in patients with imGF is included. Pre- transplant irEPO was not significantly different in both groups $(P>0 \cdot 15)$. During the phase of excretory failure, median EPO values in patients with dGF increased only slightly from $15(12-18) \mathrm{mu} \mathrm{ml}^{-1}$ to $22.7 \pm 5 \mathrm{mU} \mathrm{ml}^{-1}$ (mean \pm SD of daily median values between days 4 and $24 ; P<0.001$ vs. patients with imGF) and were generally below the lower quartile of those in patients with imGF. However, irrespective of the lower median irEPO levels, the absolute range of irEPO levels in patients with dGF was considerably higher, and maximum values in these patients markedly exceeded those during imGF. The lower median EPO values were obviously not due to higher erythrocyte mass, since haemoglobin concentrations were even slightly below those in patients with imGF $\left(8 \cdot 7 \pm 0.7 \mathrm{~g} \mathrm{dl}^{-1}\right.$ vs. $9 \cdot 7 \pm 0.6 \mathrm{~g} \mathrm{dl}^{-1}$; mean \pm SD of daily median values; $P<0.001)$. Furthermore, except patient no. 16 (see below) none of the patients with $\mathrm{dGF}$ was transfused.

Analysis of the time-course of irEPO levels in individual patients with dGF revealed two typical

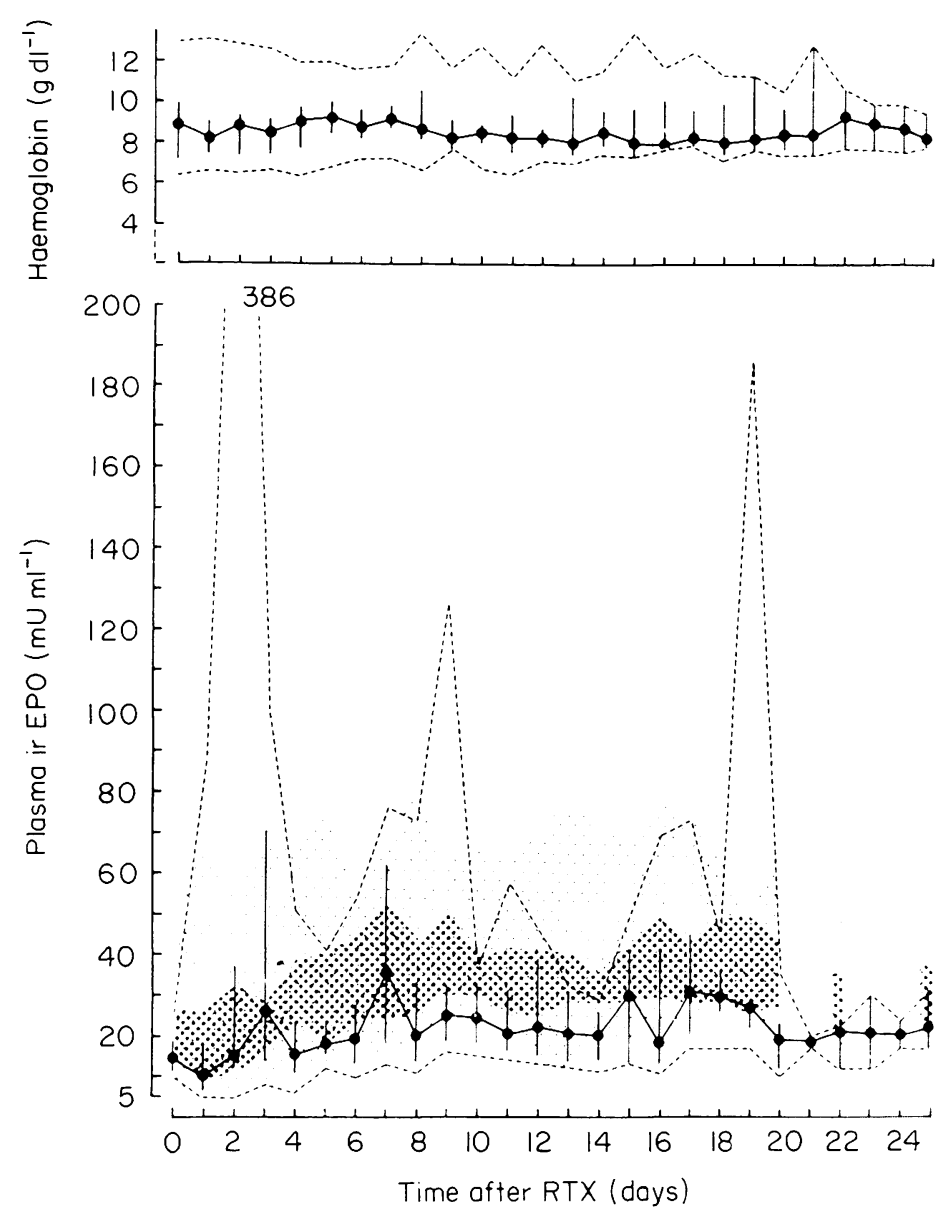

Figure 3. Temporal pattern of haemoglobin (upper) and plasma irEPO (lower) concentrations in 12 patients with dGF, including only values during the phase of excretory graft failure (serum creatinine $>300 \mu \mathrm{mol}^{-1}$ ). Values are median (filled circles) with interquartile range (solid bars) and absolute range (broken line). For comparison, interquartile range (dark stippled) and absolute range (light stippled) of plasma irEPO in patients with imGF is included. Except on days 7-9 and 11, median irEPO in patients with dGF was not significantly different from pre-transplant values. On days, 4-6, 8-11.14 and 20. median irEPO in patients with $\mathrm{dGF}$ was significantly lower than in patients with imGF. 
Table 2. Graft function and irEPO levels in patients with delayed graft function

\begin{tabular}{|c|c|c|c|c|c|c|}
\hline \multirow[b]{3}{*}{ Patient no. } & \multirow{3}{*}{$\begin{array}{l}\text { Duration of } \\
\text { excretory graft } \\
\text { failure (days)* }\end{array}$} & \multirow{3}{*}{$\begin{array}{l}\text { Haemodialysis } \\
\text { After RTX }\end{array}$} & \multirow{3}{*}{$\begin{array}{l}\text { Graft biopsy } \\
\text { (days post RTX) }\end{array}$} & \multicolumn{3}{|c|}{ 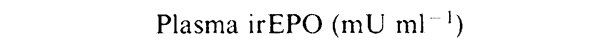 } \\
\hline & & & & \multirow{2}{*}{$\begin{array}{l}\text { Before } \\
\text { RTX }\end{array}$} & \multicolumn{2}{|c|}{$\begin{array}{l}\text { Excretory graft failure } \\
(\text { min-median-max) }\end{array}$} \\
\hline & & & & & During & After $\dagger$ \\
\hline \multicolumn{7}{|c|}{ (a) Patients with little change in irEPO during excretory graft failure } \\
\hline 16 & 40 & yes & slight REJ (9) & 18 & $13-19-31$ & $26-39-45(15)$ \\
\hline 20 & 34 & yes & $\begin{array}{l}\text { ATN (4); slight REJ, } \\
\text { vasculopathy }(25)\end{array}$ & 15 & $9-19-27$ & not determined \\
\hline 22 & 6 & no & not performed & 20 & $20-22-30$ & $20-29-49(18)$ \\
\hline 23 & 20 & yes & ATN, slight REJ (4) & 9 & $8-12-25$ & $11-20-28(31)$ \\
\hline 25 & 17 & yes & slight REJ (8) & 25 & $8-14-27$ & $27-36-45(15)$ \\
\hline \multicolumn{7}{|c|}{ (b) Patients with transient elevations in irEPO during excretory graft failure } \\
\hline 17 & 20 & yes & $\operatorname{ATN}(12)$ & 12 & $18-35-213$ & $43-53-66(6)$ \\
\hline 18 & 28 & yes & $\begin{array}{l}\text { slight REJ, } \\
\text { tubular necrosis, } \\
\text { vasculopathy }(10) \text {; } \\
\text { REJ, vasculopathy (19) }\end{array}$ & 14 & $11-22-386$ & $29-38-61(22)$ \\
\hline 19 & 17 & yes & REJ & 14 & $10-33-127$ & $21-31-43(6)$ \\
\hline 21 & 7 & no & not performed & 17 & $8-12-85$ & $15-22-50(16)$ \\
\hline 24 & 8 & yes & not performed & 12 & $7-22-68$ & $20-31-40(17)$ \\
\hline 26 & 11 & no & not performed & 5 & $5-15-57$ & $12-19-32(11)$ \\
\hline 27 & 19 & no & not performed & 34 & $16-30-168$ & $31-51-100(23)$ \\
\hline
\end{tabular}

\footnotetext{
* Days post RTX, during which serum creatinine values were above $300 \mu \mathrm{mol}{ }^{-1}$.

$\dagger$ Numbers in parentheses are number of observations after excretory graft failure.

REJ rejection; ATN, acute tubular necrosis.

In patient no. 20 EPO determinations could not be continued because he was transferred to another hospital.
}

patterns, according to which patients could be grouped (Table 2). Five patients (Nos 16, 20, 22, 23 and 25) did not show any significant increase in irEPO levels during the phase of excretory failure and no single value exceeded $31 \mathrm{mU} \mathrm{ml}^{-1}$, while the median pretransplant value was $18(15-20) \mathrm{mU} \mathrm{ml}^{-1}$. An increase in irEPO into the range of values in patients with imGF occurred, however, after excretory function had resumed (Table 2). Daily irEPO values for one of these patients (no. 16) are illustrated in Fig. 4. During the first 40 post-transplant days there were only very slight changes in irEPO concentrations and an obvious increase of irEPO was not observed until excretory graft function commenced. At that time irEPO increased, even though haemoglobin concentrations due to blood transfusion were approximately $3 \mathrm{~g} \mathrm{dl}^{-1}$ higher than during the early phase.

In the remaining patients with dGF (nos 17-19, 21, $24,26 \& 27)$ irregular transient increases in irEPO levels were observed during the period of excretory graft failure with peak levels up to $368 \mathrm{mU} \mathrm{ml}^{-1}$ and baseline values that were not different from pretransplant levels (group B, Table 2). In these patients a sustained elevation in EPO was also found after the end of excretory graft failure and at the same time intra-individual variations became less pronounced (Table 2). Figure 5 demonstrates a typical example for this pattern of irEPO levels (no. 18). It is apparent that the variations in irEPO concentrations were not related to changes in haemoglobin concentration. With the onset of excretory function irEPO levels approached the values found in patients with imGF.

Individual duration of excretory graft failure and histological diagnosis in those patients biopsied are included in Table 2. Median cold ischemia time of grafts in patients with little change in irEPO (group A) was $2030 \mathrm{~min}$ (range: 1528-2450 min) and slightly higher than in patients with transient elevations in irEPO (group B) (median: 1645 min; range: 1390-2259 min) $(P<0.05)$. Analysis of medication in patients with imGF and dGF revealed no single drug or therapeutic scheme that was consistently associated with a specific pattern of EPO levels following RTX. As expected, additional immunosuppression with azathioprine had been mainly given to patients in the group with dGF (nos 16-18, 20-23, 25 and 27). However, application of azathioprine did not correlate with different time-courses of EPO levels in these patients and was also given to two graft recipients with imGF (nos 1 and 2). Furosemide and calcium antagonists were also given to patients in both groups with different graft function (nos 4, 5, 7, 9, 11, 13, 16, 18, 19 , 21-24, 26, and 27 and nos 4, 6, 7, 8, 11, 12, 14, 15, 18, 21 and 22 , respectively). Some patients received addi- 

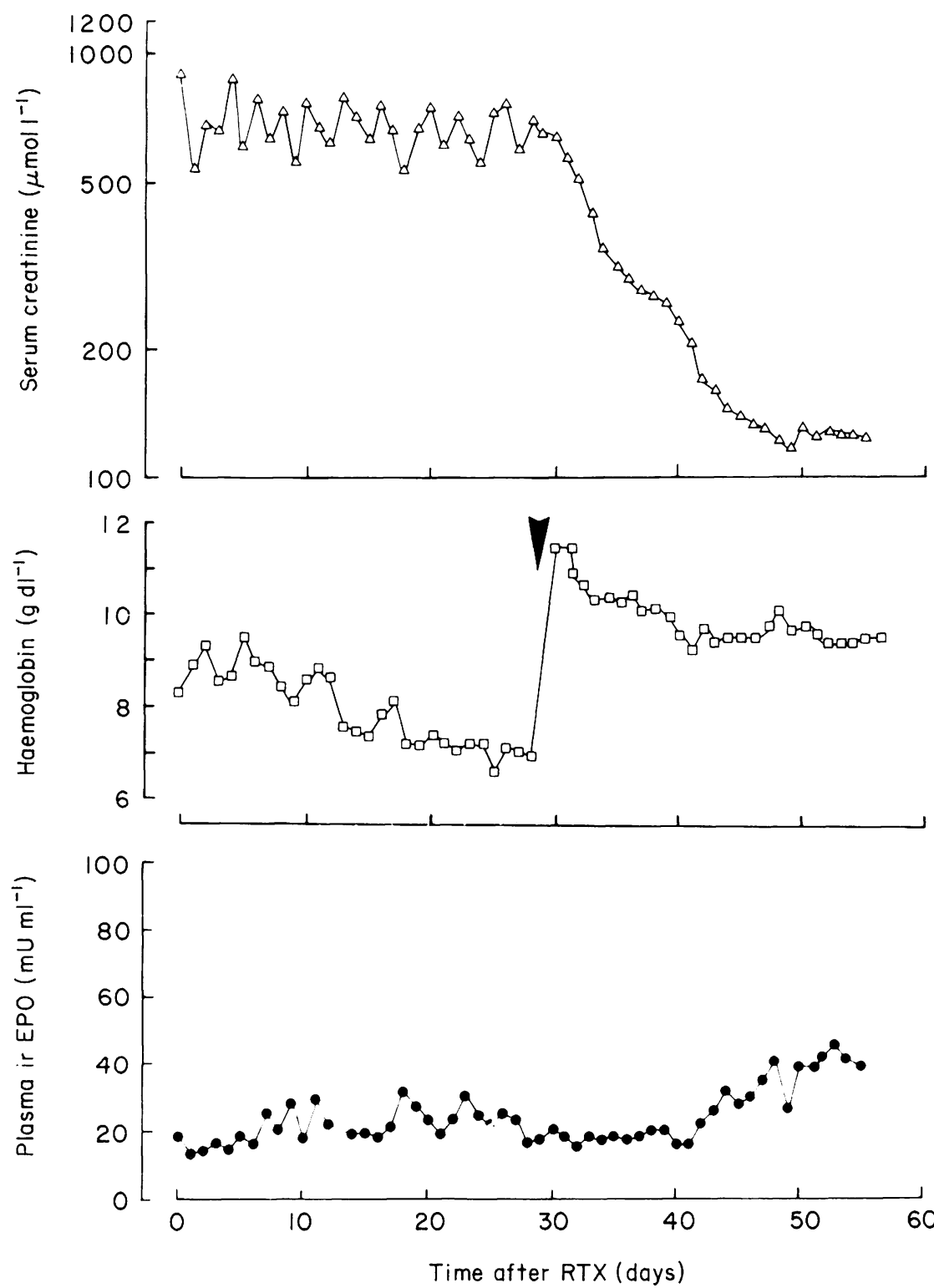

Figure 4. Time-course of serum creatinine (upper), haemoglobin (middle) and plasma irEPO (lower) concentrations in a patient with dGF (no. 16). During the first 40 days post-transplantation there was only very slight change in irEPO levels despite continuously declining haemoglobin concentrations until day 28. and a subsequent rise in haemoglobin levels following transfusion of two units erythrocytes on day 29 (arrow). An obvious increase in irEPO occured only after day 40, when excretory graft function had commenced.

tional antihypertensive medication with $\beta$-blocking agents (nos 11,18 and 23), clonidine (nos 7,17,23 and 26) or a converting enzyme inhibitor (no. 11).

\section{Discussion}

Before the availability of recombinant human EPO for replacement therapy, renal transplantation was virtually the only way to correct the anaemia of end-stage renal disease. Early studies employing bioassays for EPO demonstrated that this correction of anaemia after RTX was frequently associated with an increase of EPO in graft recipients [10-12]. However, the low sensitivity of the bioassays available at that time made it difficult to precisely assess the pattern of EPO formation after RTX. Subsequent studies have shown that a rise in EPO may be detectable within 1 to 3 days following RTX when radioimmunoassays are being used [5-7]. The sensitivity of these immunoassays is about tenfold higher than that of bioassays and the validity of immunoassay determinations is confirmed by a close correlation of bioactivity and immunoreactivity at higher concentrations of the hormone $[9,13]$.

The present study indicates that the kinetics of irEPO formation following RTX are variable, depending on the excretory function of the graft. In patients with imGF, EPO levels increased continuously after RTX and reached a plateau after about 1 week (Fig. 1). 

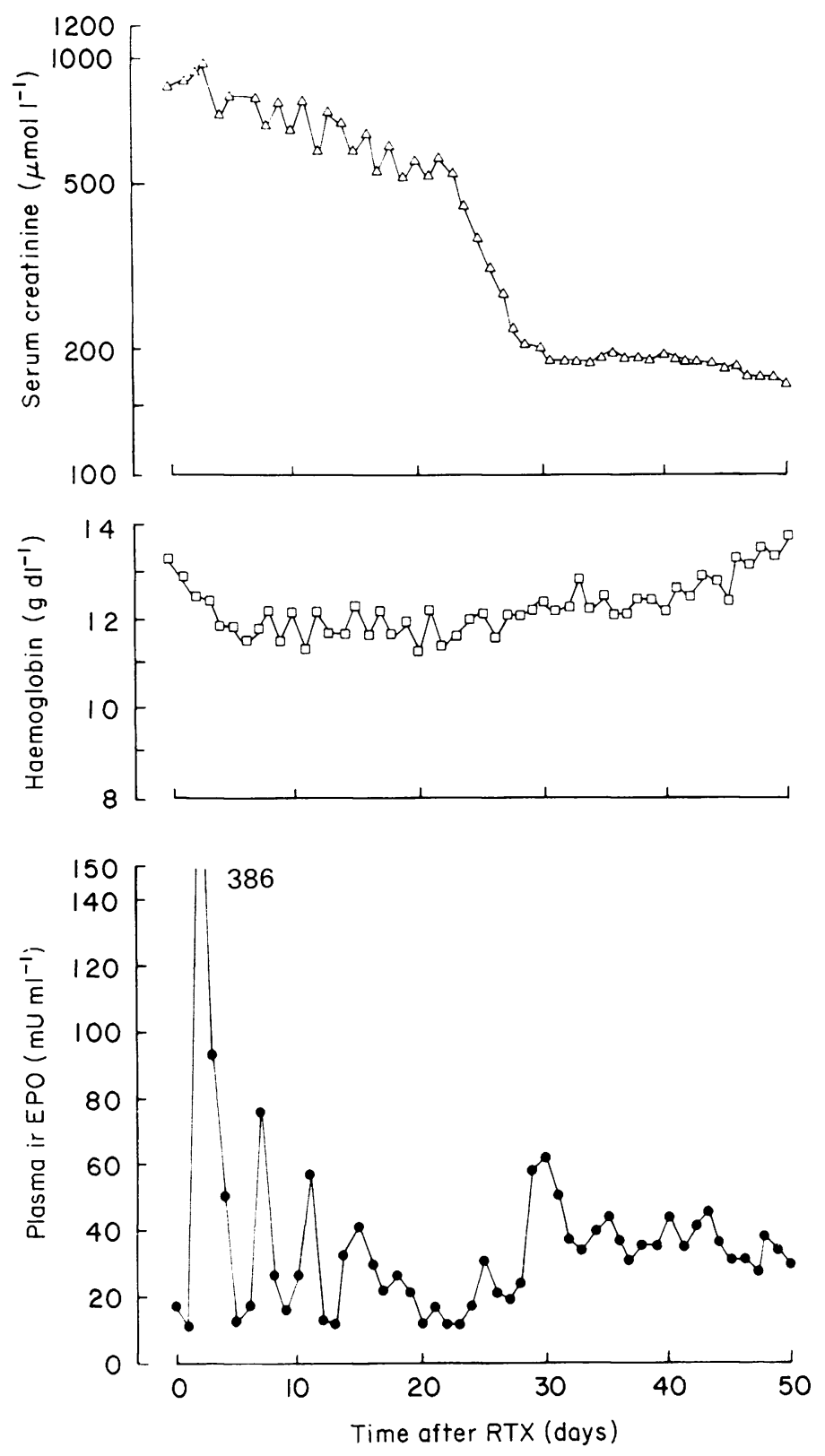

Figure 5. Time course of serum creatinine (upper), haemoglobin (middle) and plasma irEPO (lower) concentrations in a patient, in whom irEPO levels showed marked variations during the phase of excretory graft failure (no. 18). A continuous increase in irEPO alike in patients with imGF, occured after day 28 when excretory graft function had commenced.

This temporal pattern confirms qualitatively and extends two previous studies, also employing radioimmunoassays, that demonstrated early increases of irEPO after RTX [5,7]. In contrast to Besarab et al. [7], who found a typically a fourfold increase in EPO within the first 2 post-transplant weeks, increases were less pronounced, and only about two- to threefold in our patients. This difference may be related to various factors, including individual haemoglobin concentrations, immunosuppression and additional drug therapy. More importantly, the questions arise if EPO formation following RTX is subject to oxygen-dependent regulation and if the moderate increase in irEPO

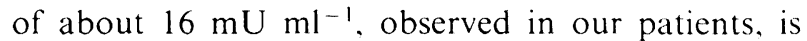
appropriate in comparison with non-renal failure patients. According to the relationship between EPO levels and haematocrits or haemoglobin concentrations established by Erslev et al. [14] and Cotes [13] for non-renal anaemias, the median EPO concentration of $34 \mathrm{mU} \mathrm{ml}^{-1}$ during the plateau phase would fit into the confidence limits for the actual haemoglobin concentration, even though only one intact kidney contributes to the rise in EPO. Also the increase in EPO in two patients having acute blood loss (Fig. 2) is well in accordance with the normal inverse exponential relationship between EPO and haemoglobin concentra- 
tions. In addition, the EPO formation in grafted kidneys tends to decline again once anaemia ameliorates $[5,7,8,15]$ (Fig. 1), also indicating an intact regulation. Regarding the erythropoietic responsiveness to EPO, it remains nevertheless noteworthy, that after restoration of renal function a relatively slight increase in EPO levels is sufficient for the correction of renal anaemia.

Taken together, the findings in patients with imGF suggest a regulated EPO formation in grafted kidneys that parallels the onset of excretory function. Since transplants lack innervation and lymph drainage, two factors that have been implicated in EPO formation and secretion $[16,17]$, neither appear to be essential for a regular increase of EPO levels.

To assess the importance of excretory graft function for EPO formation, kinetics of EPO levels in patients with dGF (Figs 3-5; Table 2) can be compared with that in patients with imGF. During the phase of excretory failure we found no EPO formation in these patients that appeared to be regulated by haemoglobin concentrations. In some patients (group A, Table 2) EPO levels did not change at all in response to the preexisting anaemia or additional blood loss (Fig. 4). In others (group B, Table 2) marked variations of EPO were found that exceeded the values in patients with $\mathrm{imGF}$ and were not related to changes in haemoglobin concentrations (Fig. 5). A comparatively high increase in EPO within the first week after RTX was recently also observed by Sun et al. [8], who averaged EPO levels in 31 transplant recipients. Although these investigators did not analyse their data separately according to different degrees of excretory graft function, the mean serum creatinine level in the whole group did not decline until day 10 , suggesting that many of their patients would have met our criteria of $\mathrm{dGF}$.

Although we cannot definitely exclude the possibility that the native kidneys or the liver are responsible for some of the acute variations of circulating irEPO in patients with dGF, several lines of indirect evidence suggest that these increased amounts of EPO are mainly derived from the grafted kidneys. First, in patients with ESRD, serum EPO values do not generally exceed the normal range of non-anaemic individuals [1,2], as was also obvious from the pretransplant values recorded in this investigation. Some variations in serum EPO in untransplanted patients have been observed in response to hypoxia [18,19], but these increases have not been of the extent seen in the present investigation. Second, the occurence of these spiking elevations was confined to periods of excretory graft failure and, third, was not associated with any specific type of underlying renal disease. In particular none of our patients in this group had polycystic kidneys, whereas Besarab et al. [7] found an early EPO peak in association with this disease. Experimental results in animals [20] and indirect evidence in humans [21] indicate that kidneys contain no stores for EPO, which could have been released, and it appears, therefore, that de novo synthesis of EPO in the grafted kidney was stimulated, apparently independent of blood oxygen-carrying capacity. From the data recorded in this study we were unable to define the nature of these stimuli. Both groups of patients, those without increase in EPO during excretory graft failure as well as those with transient elevations, comprised cases with different causes of graft failure and we found no association with the duration of graft failure or haemodialysis and drug treatment. The observation that in the group of patients with little increase in irEPO the cold ischaemia time of the grafts was higher than in patients with temporary elevations in irEPO, might indicate that EPO formation depends partially on the initial quality of the graft. Furthermore, among the possible determinants of EPO synthesis, direct drug effects on EPO-producing cells, e.g. effects of cyclosporine, as well as renal haemodynamic alterations, tissue injury and release of inflammatory cytokines, have to be considered. Although in the intact kidney reduction in arterial renal blood flow is only a minor stimulus for EPO formation [22], abnormal perfusion in kidneys with minimal excretory function or regional vasoconstriction may be of more significance.

Irrespective of the cause, the transient high EPO concentrations in some patients indicate that the failure to adequately respond to the anaemia during excretory graft failure was not due to lack of ability to synthesize the hormone. Consequently it appears, rather that the oxygen dependent regulation of EPO is disturbed during excretory graft failure. Since the mechanisms underlying the physiologic regulation of EPO are poorly understood, the reason for this disturbance remains speculative as well. Thus it is possible that a local factor associated with the pathophysiological derangements in the non-functioning graft inhibits the regulatory processes. Alternatively, the failure to adequately and continuously regulate EPO formation may indicate that ongoing excretory renal function is a prerequisite for the adaptation of EPO to changes in blood oxygen content. Although the cells producing EPO are probably not part of the nephron, but located in the cortical interstitium $[23,24]$, experimental evidence indicates that the regulation of EPO is related to tubular function [25] and this may account for the temporal concurrence between onset of excretory graft function and regulated EPO formation in both groups of patients with $\mathrm{dGF}$ as well as in patients with imGF.

In conclusion, we have shown that EPO formation after renal transplantation is related to excretory graft function. The onset of excretory graft function turned out not to be an absolute requirement for EPO production, but the oxygen-dependent regulation of EPO seems to operate only in the presence of excretory function. Regarding untransplanted patients with ESRD, this suggests that the lack of excretory function in their diseased kidneys may contribute to the 
inappropriately low EPO formation that accounts for the development of renal anaemia.

\section{Acknowledgments}

The rabbit antiserum against human EPO used in the RIA was a generous gift from Dr P. Hirth, Boehringer Mannheim, FRG.

This study was partially supported by the Swiss National Science Foundation (grant 31-9433.88).

The technical assistance of S. Graf, U. Vogel and W. Gehret is gratefully acknowledged.

\section{References}

1 Eschbach JW. Adamson JW. Anemia of endstage renal disease (ESRD). Kidney Int 1985:28:1-5.

2 Cotes PM. Pippard MJ. Reid CDL, Winearls CG. Oliver DO. Royston JP. Characterization of the anaemia of chronic renal failure and the mode of its correction by a preparation of human erythropoietin ( $r-\mathrm{HuEPO}$ ). An investigation of the pharmacokinetics of intravenous erythropoietin and its effects on erythrokinetics. Quart J Med 1989: (New Series 70):262:113-37.

3 Nielson OJ, Thaysen JH. Erythropoietin deficiency in acute renal failure., Lancet 1989:ii:624 (letter).

4 Lipkin GW, Kendall R. Hagett P. Turney JH, Brownjohn AM. Erythropoietin in acute renal failure. Lancet 1989;i:1026 (letter).

5 Rejmann ASM. Grimes AJ. Cotes PM. Mansell A. Joekes AM. Correction of anaemia following renal transplantation: serial changes in serum immunoreactive erythropoietin, absolute reticulocyte count and red-cell creatinine levels. $\mathrm{Br} \mathrm{J}$ Haematol 1985:61:421-31.

6 Besarab A, Caro J, Jarrell BE. Burke JF. Francos G, Mallon E. Karsch R. Effect of cyclosporine and delayed graft function on posttransplantation crythropoiesis. Transplantation 1985:40: 624.31

7 Besarab A. Caro J, Jarell BE. Francos G. Erslev AJ. Dynamics of erythropoiesis following renal transplantation. Kidney Int 1987:32:526-36.

8 Sun $\mathrm{CH}$. Ward HJ, Wellington LP. Koyle MA, Yanagawa N. Lee DBN. Serum erythropoietin levels after renal transplantation. New Engl J Med 1989:321:151-7.

9 Eckardt K-U, Kurtz A. Hirth P. Scigalla P. Wieczorek L. Bauer C. Evaluation of the stability of human erythropoietin in samples for radioimmunoassay. Klin Wochenschr 1988:66:241 5.

10 Denny WF. Flannagan WJ. Zukowski CJ. Serial erythropoietin studies in patients undergoing renal transplantation. J Lab Clin Med 1966;61:386-97.

11 Abbrecht PH, Greene JA. Serum erythropoietin after renal transplantation. Ann Int Med 1966;65:908 21.

12 Mirand EA, Murphy GP. Erythropoietin alterations in patients with uremia, renal allografts. or without kidneys. JAMA 1969;209:392-8.

13 Cotes PM. Immunoreactive erythropoietin in serum. I. Evidence for the validity of the assay method and the physiological relevance of estimates. Br J Haematol 1982:50:427 38 .

14 Erslev AJ, Wilson J. Caro J. Erythropoietin titers in anemic, nonuremic patients. J Lab Clin Med 1987:109:429 33.

15 Keusch G. Kurtz A. Fehr J, Eckardt K-U. Frei D. Batuer C. Binswanger U. Erythropoiese und Serumerythropoietinkonzentration vor und nach Nierenallotransplantation. Nephron 1989:51 (suppl. 1):29 33.

16 Fink GD. Fisher JW. Erythropoietin production after renal denervation or beta-adrenergic blockade. Am J Physiol 1976:230:508 13 .

17 Murphy MJ. MacPherson GG. Camiscoli JF. Gordon AS: Erythropoietin in renal and hepatic lymph of conscious ewes. Exp Hematol 1977:5:41-50.

18 Walle AJ. Wong GY. Clemons GK. Garcia JF. Niedermayer W. Erythropoietin-hematocrit feedback circuit in the anaemia of end-stage renal disease. Kidney Int 1987:31:12059.

19 Blumberg A. Keller H. Marti HR. Effect of altitude on erythropoiesis and oxygen affinity in anaemic patients on maintenance hemodialysis. Eur J Clin Invest 1973:3:93-7.

20 Jelkmann W. Bauer C. Demonstration of high levels of erythropoietin in rat kidneys following hypoxic hypoxia. Pflügers Arch 1981:392:34 39 .

21 Eckardt K-U. Boutellier U, Kurtz A. Schopen M. Koller EA. Bauer C. Rate of erythropoietin formation in humans in response to acute hypobaric hypoxia. J Appl Physiol 1989:66:1785-8.

22 Pagel H, Jelkmann W. Weiss C. A comparison of the effects of renal artery constriction and anemia on the production of erythropoietin. Pflügers Arch 1988;413:62-6.

23 Lacombe C. DaSilva J-L. Bruneval P, Fournier JG. Wendling F. Casadevall N. Camilleri JP. Bariety J. Varet B. Peritubular cells are the site of erythropoietin synthesis in the murine hypoxic kidney. J Clin Invest 1988:81:620 3.

24 Koury ST. Bondurant MC. Koury MJ. Localisation of erythropoietin synthesizing cells in murine kidney by in situ hybridization. Blood 1988:71:524 7.

25 Eckardt K-U. Kurtz A. Bauer C. Regulation of erythropoietin formation is related to proximal tubular function. Am J Physiol 1989:256:F942 8 . 